\title{
The efficacy of ampicillin vs. cephalosporins in the treatment of community adquire pneumonia in inpatient children hospital III Grau
}

\begin{abstract}
Introduction: Community adquire pneumonia (CAP) is one of the most serious diseases in the childhood. It is necessary to choose the correct antibiotic. Bacterial resistance complicates the therapy and makes it necessary to use new antibiotics; so young doctors have poor experience to use penicillin.

Objective: To compare clinical effectiveness of ampicillin to 1 st and 3rd generation cephalosporin in the treatment of community adquire pneumonia in inpatient children.

Patients and methods: Descriptive retrospective study, included children inpatient in Emergencias Grau Hospital III Essalud Lima Perú, from 2 months to 5 years old, from July 2013 to July 2014. Clinical variables of antibiotic groups were compared. Effectiveness was analyzed with Kaplan Meier curves - Log Rank method. Survival to treatment was determined by time between starting and change of antibiotic.

Results: 149 children were included, $50 \%$ were under one year old, $87 \%$ were diagnosed as bronchopneumonia and acute bronchial obstructive syndrome (ABOS) and $11 \%$ CAP. Antibiotics: ampicillin 52\%, cefazolin 25\%, ceftriaxone $16 \%$ and claritromycin $4 \%$. Statistically significant results favored ampicillin: more indicated in under one year old $(\mathrm{p}=0,01)$, respiratory distress shorter $(\mathrm{p}=0,006)$ and recovering faster $(p=0,01)$. There was no significant difference at comparing the need for antibiotic change when using ampicillin, cefazolin and ceftriaxone. It did show difference when compared to other antibiotics $(\mathrm{p}=0,012)$.
\end{abstract}

Conclusion: ampicillin is as effective as cefazolin or ceftriaxone for the treatment of CAP in children. It is suggested to follow the antibiotic ladder, to rationalize antibiotics and to avoid bacterial resistance.

Keywords: pneumonia, ampicillin, cefazolin, ceftriaxone, children, hospitalized, pneumonias

\author{
Volume 2 Issue 6 - 2018
}

\author{
Miranda Candelario Javier Francisco,' Javier \\ Espino Huamán \\ 'Bianca Miranda Candelario, Médico Pediatra Hospital Nacional \\ Alberto Sabogal Essalud, Miguel Mestanza Perea, Médico \\ Pediatra Hospital III Emergencias Grau Esalud, Peru \\ ${ }^{2}$ Servicio de Pediatría del Hospital III Emergencias Grau Essalud, \\ Médico Pediatra Emergenciólogo del Hospital III Emergencias \\ Grau Essalud, Peru
}

Correspondence: Javier Espino Huamán, Servicio de Pediatría del Hospital III Emergencias Grau Essalud, Médico Pediatra Emergenciólogo del Hospital III Emergencias Grau Essalud, Peru, Email drjaviermerandac@hotmail.com

Received: October 18, 2018| Published: November 27, 2018

\section{Introduction}

CAP is one of the most frequent and serious diseases in children. The key to prevent fatal outcomes is making an opportune diagnosis and adequate treatment. It is necessary start with an appropriate antibiotic, even though most of the etiological agents in these cases are respiratory viruses. Streptococcus pneumonia or pneumococcus is the most often cause of bacterial pneumonia in children. ${ }^{1}$ The WHO estimates that 20 million children under the age of 5 are hospitalized for severe pneumonia and that 1.2 million die annually as a result of a pneumococcal disease. ${ }^{2}$ In 2006 , pneumococcus was the cause of 18 thousand children deceased and losses of more than US \$ 340 million in Latin America, which represents two children die per hour due to complications caused by this bacterium. Bacterial resistance has complicated the treatment of pneumonias and other diseases. This has been the subject of common scientific interest in the last 10 years. ${ }^{3}$ Pneumococcal resistance usually occurs in different serotypes, but it seems to be more frequent in strains that cause disease in children. There is a hypothesis that many of these strains originated in children and later spread to adults, this idea is supported by the appearance of outbreaks of resistant pneumococci in day-care centers with prior exposure of children to antibiotics. Pneumococci are spread from person to person via the respiratory system or direct inoculation of the secretions. The microorganism can pass from the patient to the hospital staff, and these can be carriers at a high frequency. ${ }^{4}$ On the other hand, the available evidence on the evolution of patients with pneumococcal pneumonia due to microorganisms resistant to penicillin or ampicillin, does not allow to clearly demonstrate a failure of the therapy with this type of antimicrobial, more recent metaanalysis recommend it. ${ }^{5}$ However, the issue of resistance has led to the use of other antibiotics for this pathology like cephalosporins, because of their spectrum very similar to penicillin's. The WHO and the main guidelines consider that first line therapy for bacterial pneumonia continues to be penicillin or derivatives, even for infections by strains resistant to it, in which case higher doses should be used. In that sense, the problem of antibiotic resistance has led to discontinuing the use of some antibiotics that still has a good susceptibility. This is an important reason for the realization of this study, which would help to verify the limited experience that the new generation of physician has in the use penicillin for treatment of pneumonia in children. The aim of this study was to observe the clinical effectiveness of Ampicillin and cephalosporins (1st and 3rd generation) most used in our clinical practice in the treatment of community-acquired pneumonia in children. 


\section{Patients and methods}

A retrospective cohort study was conducted. The universe was all the patients who were admitted to the pediatric service of Emergencies Hospital III Grau Essalud, between July 2013 and July 2014, with CAP diagnosis. Children from 2 months to 5 years of age were selected regardless of gender, with clinical, radiological and analytical diagnosis of CAP. This age group was chosen because it is more likely that CAP is produced by Streptococcus pneumonia, although Staphylococcus aureus may be present and Haemophilus influenza. There is a risk of bias due to poor classification of treating physicians. The clinical diagnosis of pneumonia required that the patient had tachypnea, retractions accompanied by a decrease in vesicular murmur or presence of wet rales (crackles) even though there was no fever; radiological corroboration and no antibiotic therapy in the 2 weeks prior to admission. We define time to improve, as the time to take the patient to improve the general state, fever disappear, reduce respiratory distress and improve oral tolerance. All these symptoms were evaluated at 24, 48 and 72 hours. The treatment survival was determined by the time in days from the moment of initiation, until the antibiotic change. Because it was a retrospective study, there was not intervention on the type of antibiotic used.

\section{Statistical analysis}

We used SPSS program version 18 for statistical analysis. There was a descriptive analysis of frequencies, percentages and means. Means were compared by the chi-square method, the significance value was established as $p<0.05$. For the analysis of the effectiveness of the different antibiotics, Kaplan Meier survival curves were used to determine if there were statistically significant differences $(p<0.05)$ between the different treatments, the calculations were made by the Log Rank method. The study was approved by the Hospital Ethics Committee.

\section{Results}

The study group was 149 patients; all of them met the inclusion

Table I Comparison of clinical variables of groups of Antibiotics, chi-square

\begin{tabular}{|c|c|c|c|c|}
\hline & Ampicillin & Cefazolin & Ceftriaxone & $\mathbf{p}$ \\
\hline Age: 1 to 12 Month: $\mathrm{n}(\%)$ & $40(54)$ & $19(25)$ & $15(20)$ & $0,01 \mathrm{~s}$ \\
\hline Male: n (\%) & $40(49)$ & $17(48)$ & $11(48)$ & 0,25 \\
\hline Good general condition: $\mathrm{n}(\%)$ & $22(27)$ & $12(32)$ & $7(30)$ & 0,65 \\
\hline Oral intolerance: $\mathrm{n}(\%)$ & $11(14)$ & $6(18)$ & $4(19)$ & 0,85 \\
\hline Mild retraction: $\mathrm{n}(\%)$ & $56(68)$ & $26(72)$ & $18(75)$ & 0,32 \\
\hline Tachypnea: n (\%) & $49(60)$ & $24(65)$ & $16(68)$ & 0,98 \\
\hline Income temperature: mean & 37,6 & 37,4 & 37,8 & 0,09 \\
\hline $\mathrm{O} 2$ saturation: mean & 93 & 92 & 93 & 0,31 \\
\hline Time of improvement, days: mean & 1,5 & 2 & 2,3 & $0,01 \mathrm{~s}$ \\
\hline Hospital stay: mean & 5 & 5,1 & 5,2 & 0,08 \\
\hline Bronchopneumonia + Bronchial Obstructive Syndrome: n (\%) & $70(85)$ & $34(91)$ & $24(100)$ & 0,46 \\
\hline
\end{tabular}

criteria Figure 1.49, 7\% was in the range of age between 1 to 12 months; $24,2 \%$ between 13 to 24 months. The mean age was 13 months. The most frequent diagnosis was bronchopneumonia with acute bronchial obstructive syndrome, 130 patients $(87,2 \%)$; pneumonia $18(12,0 \%)$ y viral pneumonia $1(0,7 \%) .82(55 \%)$ patients were treated with ampicillin; 37 (25\%) were treated with cefazolin; 24 (16\%) with ceftriaxone and $6(4 \%)$ with clarithromycin. Table 1 analyzes if the patients of three groups of antibiotics present the same severity illness. We obtained statistically significant that those who received ampicillin were younger children and had a shorter improvement time. The other variables did not show significant differences. Table 2 compares the improvements of symptoms with each group of antibiotics:

At 24 hours: retractions disappears in $91 \%$ of those who received Ampicillin, in $62.8 \%$ of those with Cefazolin and $54.8 \%$ of those with Ceftriaxone. The polypnea disappeared $81.9 \%$ in the Ampicillin group, $58.9 \%$ with Cefazolin and $57.5 \%$ with Ceftriaxone. The fever disappeared from 100\% Ampicillin, 100\% Cefazolin and 89\% Ceftriaxone. Oral Intolerance disappeared $92.3 \%$ with Ampicillin, 100\% Cefazolin and 85.7\% Ceftriaxone. Oxygen administration was suspended 81.8\% in Ampicillin group, 57.1\% Cefazolin and 54.9\% Ceftriaxone. The desaturation disappeared $77 \%$ in Ampicillin group, $61.9 \%$ with Cefazolin and $52.3 \%$ with Ceftriaxone. Improvement was evidenced in $61 \%$ with Ampicillin group, in $43.5 \%$ with Cefazolin and in $24.2 \%$ with Ceftriaxone.

At 48 y 72 hours of treatment: retractions disappears faster $(p=$ 0.006 ) for ampicillin group, the same happened with the time of improvement $(p=0.01)$. Another clinical signs did not show significant differences between the groups of antibiotics. Figure 2 shows the need for antibiotic change, according to the Kaplan Meier Survival Analysis, and using the Log Rank method it was obtained that ceftriaxone, cefazolin and ampicillin did not show significant differences between them, but when compared with other antibiotics a difference was found significant $(\mathrm{p}=0.012)$. Thus, on the 5 th day, the efficacy of ceftriaxone was $100 \%$, of cefazolin $97 \%$ and of ampicillin $93 \%$, while for the other antibiotics it was $66 \%$.

S= significant 
The efficacy of ampicillin vs. cephalosporins in the treatment of community adquire pneumonia in

Table 2 Comparison of disappearance of symptoms with each group of antibiotics, chi square

\begin{tabular}{|c|c|c|c|c|c|}
\hline & & Ampicillin & Cefazolin & Ceftriaxone & $\mathbf{p}$ \\
\hline \multirow[t]{3}{*}{ Retractions } & $24 \mathrm{~h}$ & $91 \%$ & $62,80 \%$ & $54,80 \%$ & $0,006 \mathrm{~S}$ \\
\hline & $48 \mathrm{~h}$ & $98,50 \%$ & $82,80 \%$ & $87 \%$ & \\
\hline & $72 \mathrm{~h}$ & $100,00 \%$ & $97,00 \%$ & $90 \%$ & \\
\hline \multirow[t]{3}{*}{ Polypnea } & $24 \mathrm{~h}$ & $81,90 \%$ & $58,90 \%$ & $57,50 \%$ & 0,989 \\
\hline & $48 \mathrm{~h}$ & $95,80 \%$ & 84,605 & 81,80 & \\
\hline & $72 \mathrm{~h}$ & $100 \%$ & $97,4 \%$ & $93,9 \%$ & \\
\hline \multirow[t]{3}{*}{ Fever } & $24 \mathrm{~h}$ & $100 \%$ & $100 \%$ & $89 \%$ & 0,226 \\
\hline & $48 \mathrm{~h}$ & $100 \%$ & $100 \%$ & $94,9 \%$ & \\
\hline & $72 \mathrm{~h}$ & $100 \%$ & $100 \%$ & $100 \%$ & \\
\hline \multirow[t]{3}{*}{ Oral Intolerance } & $24 \mathrm{~h}$ & $92,3 \%$ & $100 \%$ & $85,7 \%$ & 0,485 \\
\hline & $48 \mathrm{~h}$ & $92,30 \%$ & $100 \%$ & $100 \%$ & \\
\hline & $72 \mathrm{~h}$ & $100,00 \%$ & $100 \%$ & $100 \%$ & \\
\hline \multirow[t]{3}{*}{ Desaturation } & $24 \mathrm{~h}$ & $77 \%$ & $61,90 \%$ & $52,30 \%$ & 0,930 \\
\hline & $48 \mathrm{~h}$ & 95,85 & $95,20 \%$ & $90,40 \%$ & \\
\hline & $72 \mathrm{~h}$ & $100 \%$ & $100 \%$ & $90,4 \%$ & \\
\hline Need for & $24 \mathrm{~h}$ & $81,80 \%$ & $57,10 \%$ & $54,50 \%$ & 0,65 \\
\hline \multirow[t]{2}{*}{ oxygen } & $48 \mathrm{~h}$ & $90,90 \%$ & $85,70 \%$ & $81,80 \%$ & \\
\hline & $72 \mathrm{~h}$ & $90,9 \%$ & $85,7 \%$ & $81,8 \%$ & \\
\hline Time of & $24 \mathrm{~h}$ & $61 \%$ & $43,50 \%$ & $24,20 \%$ & $0,01 \mathrm{~S}$ \\
\hline \multirow[t]{2}{*}{ improvement } & $48 \mathrm{~h}$ & $88,80 \%$ & $82 \%$ & $63,60 \%$ & \\
\hline & $72 \mathrm{~h}$ & $100 \%$ & $97,4 \%$ & $81,8 \%$ & \\
\hline Hospital & $<4$ days & $26,30 \%$ & $17,90 \%$ & $15,10 \%$ & 0,616 \\
\hline \multirow[t]{2}{*}{ stay } & 5- 7 days & $70,80 \%$ & $79,40 \%$ & $72,70 \%$ & \\
\hline & $>8$ days & $2,7 \%$ & $2,5 \%$ & $12,10 \%$ & \\
\hline
\end{tabular}

S, significant

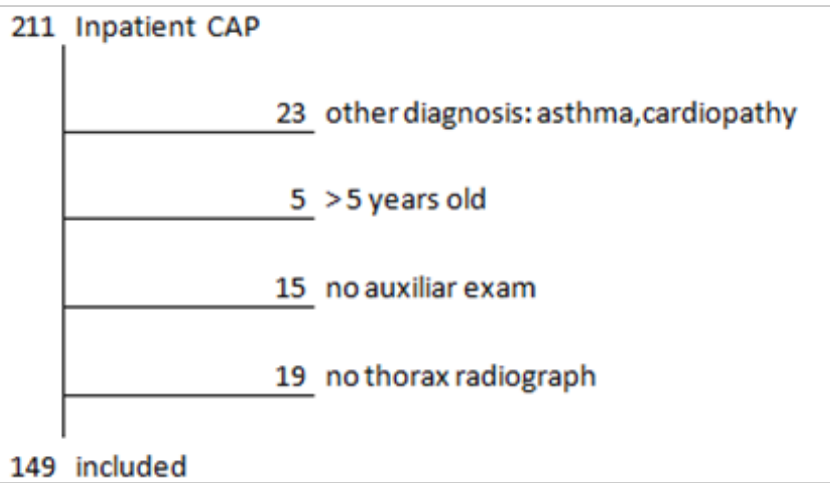

Figure I Patients selection.

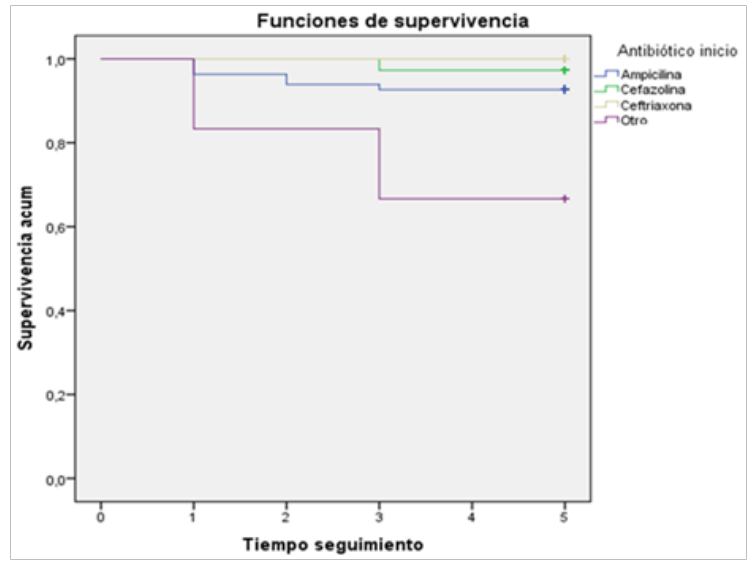

Figure 2 Need for antibiotic change. 


\section{Discussion}

The study of pneumonia always brings controversies. There are areas of uncertainty in the management of CAP such as the difficulty in differentiating viral from bacterial pneumonia, the difficulty in determining the specific etiological agent, and the difficulty in selecting the appropriate antibiotic treatment. ${ }^{6}$ A review of 14 studies with 1596 samples obtained by pulmonary aspiration in children hospitalized with pneumonia found $62 \%$ of bacterial pathogens. ${ }^{7}$ Nasopharyngeal swab studies found that about $40 \%$ of pneumonia cases in children under 5 years old were viral. ${ }^{8}$ A national study made in two ecologically distinct zones found $55 \%$ of CAP caused by viruses and $20.7 \%$ by bacteria, and viruses affected younger children. ${ }^{9}$ The present study has evidence that the most affected population was younger than 2 years old, this age group where viral pneumonias is frequent it is characterized by wheezing, which justifies that $87 \%$ had a diagnosis of bronchopneumonia associated with acute bronchial obstructive syndrome. It is important an appropriate intervention with antibiotics to reduce the mortality associated with pneumonia. The decision to start antibiotic therapy must be base that the most frequent bacterial etiologic agent since 3 months of age is pneumococcus, and the selection of first-line antibiotics is crucial to improve the outcome of pneumonia. ${ }^{10}$ WHO recommends hospitalization and treatment of severe and very severe pneumonia with Penicillin or Chloramphenicol? The last meta-analysis conducted by Lodka et al in children hospitalized with severe and very severe CAP, found that penicillin or ampicillin associated with gentamicin is superior to chloramphenicol and should be considered first-line antibiotics. Second line antibiotics were ceftriaxone, levofloxacin, clavulanic acid plus amoxicillin, and cefuroxime, which would be start when penicillin fails or when there is a suspicion of aggravation of the clinical status. ${ }^{11}$

In the literature, cefazolin is not taken into account, it should not be used in respiratory infections of lower airways when the probable germ is Hemophilus influenza or Moraxella catarralis; ${ }^{12,13}$ however, in practice it is widely used with relative success. Multiple antibiotics are prescribed for the treatment of pneumonia, often motivated by fear of resistance and the need to ensure a good clinical outcome. Therefore, it is important to know which the best scheme is. The cure and failure rates of CAP depend not only on the choice of antibiotics, it is also important the etiology of pneumonia, the age of the patient and the severity of the disease. ${ }^{14}$ It is know that in vitro resistance to penicillin and derivatives in our country reaches $25 \%$. There are different therapeutic strategies for the management of resistant pneumococcal infections, such as increasing doses, which allows an increase in plasma levels in such a way that serum concentrations of beta-lactams exceed the minimum inhibitory concentration of all resistant pneumococcal strains. ${ }^{15}$ In our study, we observed that ampicillin is as effective as cefazolin or ceftriaxone, not finding statistical differences in the decrease of polypnea and fever, the improvement of oral tolerance and the time of permanence. In addition, the Ampicillin group has a greater number of children under 1 year old, a group considered always at high risk; and however, the disappearance of retractions was faster and the time of improvement was significantly less than cefazolin or ceftriaxone group. This also has demonstrated with the survival curve, where we see that there are no significant differences between these three antibiotics. These results are very similar to Simbalista in Brazil. ${ }^{16}$ We must mention that in our review, no patient received only penicillin, or penicillin associated with gentamicin.
It is known that the increase in resistance to a certain antibiotic is directly related to the antecedent of exposure to the same antibiotic or another of the same family. In developed countries where the exposure of antibiotics has decreased, an important decrease in antibiotic resistance has been observed. On the other hand, in countries such as ours, the misuse of antibiotics continues unfortunately, especially in the pediatric population where prescription and self-medication are observed for viral infections, with the consequent increase in resistance ${ }^{17,18}$ It is necessary to carry out educational campaigns for the general population on the use of antibiotics, their benefits and risks, which is antibiotic resistance. In the medical community, we must rescue the sensibility of penicillin and derivatives in this type of diseases, which should be reinforced with national clinical guidelines to guide doctors in the prescription of antibiotics supported by scientific evidence.

\section{Conclusion}

Ampicillin is as effective as Cefazolin or Ceftriaxone for the treatment of CAP in children. The therapeutic scale should be followed to rationalize antibiotics and decrease bacterial resistance.

\section{Acknowledgments}

None.

\section{Conflicts of interest}

The auhtor declares there is no conflicts of interest.

\section{References}

1. Gastón B. Neumonía. Pediatrics in Review. 2002;23(4):132-140.

2. Rudan I, Boschi C, Bioglav Z, et al. Epidemiology and etiology of childhood pneumonia. Bull World Health Organ. 2008;86(5): 408-416.

3. Rudan I, Tomaskovic L, Boschi-Pinto C, et al. Global estimate of the incidence of clinical pneumonia among children under five years of age. Bull World Health Organ. 2004;82(12):895-903.

4. Korpi M, Heiskanen-Kosma, Jalonen E, et al. Aetiology of communityacquired pneumonia in children treated in hospital. Eur J Pediatr. 1992;152(1):24-30.

5. Lassi Z, Das J, Haider S, et al. Systematic review on antibiotic therapy for pneumonia in children between 2 and 59 months of age. Arch Dis Chil. 2004;99(7):687-93

6. Borsotti M, Moreno L, Bujedo E, et al. Prescripción de antibióticos en lactantes hospitalizados con neumonía por virus sincicial respiratorio. Arch Argent Pediatr.2008;106(6).

7. Berman S. Epidemiology of acute respiratory tract infection in children of developing countries. Reviews of Infectious Diseases. 1990;13(Suppl $60): 454-467$.

8. Resti M, Moriondo M, Cortiglia M, et al. Community- acquired bacteremic pneumococcal pneumonia in children: diagnosis and serotyping by realtime polymerase chain reaction using blood samples. Clin Infect Dis. 2010;51(9):1042.

9. Padilla J, Lindo F, Rojas R, et al. Perfil etiológico de la neumonía adquirida en la comunidad en niños de 2 a 59 meses en dos zonas ecológicamente distintas del Perú. Arch Argent Pediatr. 2010;108(6):516-523.

10. Kaplan S, Mason E. Six year multicenter surveillance of invasive pneumococcal infections in children. Pediatr Infect Dis J. 2002;21:141147. 
11. Lodha R, Kabra s, Pandey R. Antibiotics for community acquired pneumonia in children. Cochrane acute respiratory Infectious Group. 2013;4(6):CD004874

12. Guía Básica Farmacoterapeutica. Complejo Hospitalario Universitario Juan Canalejo. $5^{\text {th }}$ edition. 2002. p. 393-399.

13. Heinz Lullmann, Klaus Mohr, Slbrecht Ziegler. Color Atlas of Pharmacology. $2^{\mathrm{a}}$ Edition Thymes New York, 2000.

14. The WHO Young Infants Study Group. Bacterial etiology of serious infections in young infants in developing countries: results of a multicenter study. Pediatr Infect Dis J. 1999;18(Supple 10):S17-S22.

15. Álvarez P Ana. Neumonía Adquirida en la Comunidad en niños:
Aplicabilidad de las guías clínicas. Rev Chil Infect. 2003;20 (Supple 1):S59-S62

16. Simbalista R, Araujo M, Nascimento-Carvalho C. Outcome of children hospitalized with community- acquired pneumonia treated with aqueous penicillin G. Clinics (Sao Paulo). 2011;66(1):95-100.

17. Moreno L, Krishnan J, Duran P, et al. Development and validation of a clinical prediction rule to distinguish bacterial from viral pneumonia in children. Pediatr Pulmonol. 2006;41(4):331-337.

18. Guía Práctica clínica. Neumonía Adquirida Comunidad niños. Perú 2009, Sociedad Peruana de Enfermedades Infecciosas. OPS- OMS. 2009. p. $1-70$. 